\title{
Intraoperative ventilator settings and their association with postoperative pulmonary complications in neurosurgical patients: post-hoc analysis of LAS VEGAS study
}

Chiara Robba ${ }^{1 *}$, Sabrine N. T. Hemmes ${ }^{2,3}$, Ary Serpa Neto ${ }^{2,4}$, Thomas Bluth ${ }^{5}$, Jaume Canet ${ }^{6}$, Michael Hiesmayr ${ }^{7}$, M. Wiersma Hollmann ${ }^{3}$, Gary H. Mills ${ }^{8}$, Marcos F. Vidal Melo ${ }^{9}$, Christian Putensen ${ }^{10}$, Samir Jaber ${ }^{11}$, Werner Schmid ${ }^{7}$, Paolo Severgnini ${ }^{12}$, Hermann Wrigge ${ }^{13}$, Denise Battaglini ${ }^{1,14}$, Lorenzo Ball ${ }^{1,14}$, Marcelo Gama de Abreu ${ }^{5}$, Marcus J. Schultz ${ }^{2,15}$, Paolo Pelosi ${ }^{1,14}$, FERS for the LAS VEGAS investigators and the PROtective VEntilation Network and the Clinical Trial Network of the European Society of Anaesthesiology

\begin{abstract}
Background: Limited information is available regarding intraoperative ventilator settings and the incidence of postoperative pulmonary complications (PPCS) in patients undergoing neurosurgical procedures. The aim of this post-hoc analysis of the 'Multicentre Local ASsessment of VEntilatory management during General Anaesthesia for Surgery' (LAS VEGAS) study was to examine the ventilator settings of patients undergoing neurosurgical procedures, and to explore the association between perioperative variables and the development of PPCs in neurosurgical patients.
\end{abstract}

Methods: Post-hoc analysis of LAS VEGAS study, restricted to patients undergoing neurosurgery. Patients were stratified into groups based on the type of surgery (brain and spine), the occurrence of PPCs and the assess respiratory risk in surgical patients in Catalonia (ARISCAT) score risk for PPCs.

Results: Seven hundred eighty-four patients were included in the analysis; 408 patients (52\%) underwent spine surgery and 376 patients (48\%) brain surgery. Median tidal volume $\left(V_{T}\right)$ was $8 \mathrm{ml}$ [Interquartile Range, IQR $=7.3-9$ ] per predicted body weight; median positive end-expiratory pressure (PEEP) was 5 [3 to 5] $\mathrm{cmH}_{2} \mathrm{O}$. Planned recruitment manoeuvres were used in the $6.9 \%$ of patients. No differences in ventilator settings were found among the sub-groups. PPCs occurred in 81 patients (10.3\%). Duration of anaesthesia (odds ratio, 1.295 [95\% confidence interval 1.067 to 1.572$] ; p=0.009$ ) and higher age for the brain group (odds ratio, 0.000 [0.000 to 0.189]; $p=0.031$ ), but not intraoperative ventilator settings were independently associated with development of PPCs.

Conclusions: Neurosurgical patients are ventilated with low $V_{T}$ and low PEEP, while recruitment manoeuvres are seldom applied. Intraoperative ventilator settings are not associated with PPCs.

Keywords: LAS VEGAS, Mechanical ventilation, Postoperative pulmonary complications, Neurosurgery

\footnotetext{
*Correspondence: kiarobba@gmail.com

'Anaesthesia and Intensive Care, San Martino Policlinico Hospital, IRCCS for Oncology and Neurosciences, Largo Rosanna Benzi 8, 16131 Genoa, Italy

Full list of author information is available at the end of the article
}

(c) The Author(s). 2020 Open Access This article is licensed under a Creative Commons Attribution 4.0 International License, which permits use, sharing, adaptation, distribution and reproduction in any medium or format, as long as you give appropriate credit to the original author(s) and the source, provide a link to the Creative Commons licence, and indicate if changes were made. The images or other third party material in this article are included in the article's Creative Commons licence, unless indicated otherwise in a credit line to the material. If material is not included in the article's Creative Commons licence and your intended use is not permitted by statutory regulation or exceeds the permitted use, you will need to obtain permission directly from the copyright holder. To view a copy of this licence, visit http://creativecommons.org/licenses/by/4.0/. The Creative Commons Public Domain Dedication waiver (http://creativecommons.org/publicdomain/zero/1.0/) applies to the data made available in this article, unless otherwise stated in a credit line to the data. 


\section{Background}

Lung-protective ventilation strategies are increasingly used in surgical patients $[1,2]$. Typical lung-protective strategies include the use of a low tidal volume $\left(\mathrm{V}_{\mathrm{T}}\right)$ and a low plateau pressure (Pplat), with moderate positive end-expiratory pressure (PEEP) and use of recruitment manoeuvres (RM) if needed $[1,2]$. Among these settings, a low $V_{T}$ seems to have the most protective effects compared with moderate or high PEEP $[3,4]$.

However, lung-protective ventilation is rarely used in brain injured patients, in whom median $V_{T}$ is generally $9 \mathrm{ml} / \mathrm{kg}$ of predicted body weight (PBW) [5]. The role of intraoperative ventilator settings and their potential impacts on the development of postoperative complications (PPCs) has been scarcely evaluated in neurological patients [6]. Typically, patients with neurosurgical pathologies have been excluded from most trials on protective intraoperative ventilation. This may be because lungprotective strategies could have detrimental effects on cerebrovascular physiology, and thus might be potentially contraindicated in acute neurosurgical patients [7]. Moreover, just few and inconclusive data exist regarding the ventilator settings applied in patients undergoing spinal surgery and the incidence of PPCs in this population $[8,9]$.

We therefore conducted a post-hoc analysis of the 'Local ASsessment ofVEntilatory management during General Anaesthesia for Surgery-study' (LAS VEGAS), a conveniently sized international observational study in the operating rooms of patients receiving mechanical ventilation [10]. We focused on neurosurgical patients, including patients undergoing brain or spine surgery. The aims of this analysis were to assess which ventilator strategies were used in neurosurgical patients during general anaesthesia, and to assess the incidence of PPCs and risk factors (including type of surgery, ventilator settings, risk for PPCs) associated with the development of PPCs. The main hypothesis tested was that neurosurgical patients are ventilated with high tidal volume and low positive end expiratory pressure, and that intraoperative ventilator settings can have an effect on PPCs development.

\section{Methods}

\section{LAS VEGAS study}

This article is reported as per Strengthening the Reporting of Observational Studies in Epidemiology (STROBE) reporting guidelines (www.strobe-statemenent.org) (Electronic supplementary material ESM Table S1).

LAS VEGAS [8] was an international multicentre observational prospective study (registered at www. clinicaltrials.gov (study identifier NCT01601223)), endorsed and supported by the European Society of Anaesthesiology and the Amsterdam University Medical Centres, location AMC, Amsterdam, The Netherlands. Details about the LAS VEGAS study collaborators, participating centres and hospital characteristics of participating centres are reported in ESM Tables S2a, b and S3.

All adult patients requiring invasive ventilation for surgical procedures in a time window of 7 days were included. Exclusion criteria were: age under 18 years, obstetric procedures, recent ventilation before surgery ( $<28$ days), surgical procedures not performed in the operating room, and interventions requiring cardiopulmonary bypass.

For this study, we restricted the analysis to patients receiving intraoperative ventilation for neurosurgical procedures (brain or spine surgery) (ESM Flow Chart).

\section{Data collection}

After inclusion, the following data were collected: patients' baseline and demographic characteristics; the assess respiratory risk in surgical patients in Catalonia (ARISCAT) score [11]; American Society of Anaesthesiologists (ASA) scale; details on the surgical procedure including intraoperative hourly vital parameters and ventilation data (mode of ventilation, fraction of inspired oxygen $\left(\mathrm{FiO}_{2}\right), \mathrm{V}_{\mathrm{T}}$, PEEP, peak pressure (Ppeak), respiratory rate $(\mathrm{RR}))$, end-tidal $\mathrm{CO}_{2}\left(\mathrm{ETCO}_{2}\right)$, oxygen saturation $\left(\mathrm{SpO}_{2}\right)$, number and type of recruitment manoeuvres, and intraoperative complications.

Recruitment manoeuvres were defined as 'rescue' when the recruitment manoeuvre was not part of the planned ventilation strategy and defined as 'planned' if it was part of routine ventilation practice (ESM Table S4). Mechanical power (MP) was calculated according to the following formula [12]: $0.098 \times V_{\mathrm{T}} \times \mathrm{RR} \times$ [Ppeak $\mathrm{x}$ (Pplat - PEEP)/2]. Hourly data were collected starting at the induction of anaesthesia (T1/40) and then hourly until the end of anaesthesia, up to the 7th hour of surgery $(\mathrm{T} 1 / 47)$.

\section{Endpoints}

The primary endpoint was to describe the current practice and ventilator strategies in patients undergoing neurosurgical interventions, in particular ventilator mode, $\mathrm{V}_{\mathrm{T}}$, PEEP, driving pressure, Ppeak and Pplat and $\mathrm{RR}$, as well as mechanical power.

The secondary outcome was to assess the prevalence of PPCs and the association with preoperative and intraoperative variables including mechanical ventilator settings, type of surgery, ARISCAT score. Detailed definitions of the composites of PPCs and severe PPCs are provided in ESM Table S5. Intraoperative complications included desaturation, rescue recruitment manoeuvres, need for airway pressure reduction, expiratory flow limitation, hypotension and use of vasoactive drugs, onset of a new cardiac arrhythmia (ESM Table S6). The 
occurrence of each type of PPC was monitored until hospital discharge, but maximum up to postoperative day 5 .

Other secondary endpoints included the occurrence of severe PPCs, intraoperative complications, in-hospital mortality and length of hospital stay.

\section{Statistical analysis}

Patients were stratified into groups based on type of surgery (brain and spine), the occurrence of PPCs and risk for PPC according to ARISCAT (low risk [ARISCAT < $26]$ vs. moderate-to-high risk [ARISCAT $\geq 26$ ]. Continuous variables are expressed as mean \pm standard deviation (SD) or median (interquartile range [IQR]) per variable distribution. Discrete variables are presented as percentages. Baseline characteristics among type of neurosurgery were compared by either $t$-test, Wilcoxon rank-sum test, or chi-squared tests, as appropriate. The effect of type of neurosurgery on the incidence (per $10 \mathrm{P}$-days) of in-hospital PPC, severe PPC, and discharged alive was evaluated using log-rank test (stratified by centre); differences in survival probabilities and hospital discharge were depicted with an outcome-specific Kaplan-Meier plot.

A multivariable regression model was built, with PPC as dependent variables. Because this outcome is binary $(0 / 1)$, a logistic regression analysis was applied. Candidate covariates were chosen based on previous medical knowledge, independent of their $p$-value. From this preliminary selection, those variables with $P<0.20$ in the univariate analysis were preferentially chosen for the stepwise procedure. Then, a reduced and parsimonious model was derived using backward stepwise selection. During this selection process, the linearity assumption for continuous variables was tested and transformed, if appropriate, with fractional polynomials (14). In all regression models, the Huber/White/sandwich estimator of variance correction was applied to account for any clustering effect due to centre sampling.

We set a two-sided $p$ value of $<0.05$ as the threshold for statistical significance. Stata 15.1 (Stata Statistical Software, release 15 [2017] (Stata Corp LP, College Station, TX, USA), and R (Version 3.5.3; R Foundation for Statistical Computing, Vienna, Austria) were used.

\section{Results}

A total of 784 patients were included in the analysis. Of these, 408 (52\%) underwent spine surgery and 376(48\%) brain surgery. The characteristics of the patients according to subgroups are described in Table 1. Patients with moderate-to-high risk for PPCs- compared to those at low risk were older, with a higher incidence of comorbidities (in particular chronic kidney failure), worse ASA physical status, and worse pre-hospital functional status and preoperative conditions (as for laboratory tests and vital signs) (Table 1). Patients who developed PPCs were older, with more frequent co-morbidities (in particular respiratory and cardiological), worse ASA and preoperative functional status (Table 1).

\section{Ventilation variables and intraoperative characteristics} Most of the patients underwent elective surgical procedure (72\%), with a median surgical duration of $95 \mathrm{~min}$ (1st-3rd interquartile range IQR $=60-160)$ and median anaesthetic time of $126 \mathrm{~min}$ (IQR $=90-192.8 \mathrm{~min}$ ). The most common ventilation mode was volume-controlled ventilation (VCV) (Table 2). VCV was more commonly used in patients undergoing brain surgery. Median $\mathrm{V}_{\mathrm{T}}$ was $510 \mathrm{ml}$ (Interquartile range, IQR 475-575), thus resulting in $8 \mathrm{ml} / \mathrm{kg}$ predicted body weight (IQR $=7.3-$ 9). Median PEEP level was $5 \mathrm{cmH}_{2} \mathrm{O}$ (IQR 3-5), Ppeak was $18 \mathrm{cmH}_{2} \mathrm{O}(\mathrm{IQR}=15-21)$ and driving pressure was $12(\mathrm{IQR}=11-15) \mathrm{cmH}_{2} \mathrm{O}$ (Table 2).

Routine RMs were performed in 54 patients (6.9\%). Unplanned RMs occurred in $1.4 \%$ of cases. No statistical difference was found between the spine and brain surgery group or regarding the ventilator settings (Table 2, ESM Figure S1). $\mathrm{EtCO}_{2}$ values were significantly lower in the brain surgery group compared with the spine surgery group $(p=0.001)$. Patients who developed PPCs received a higher amount of fluids compared to those with no PPCs (Table 2), but no differences were found in the ventilator settings between the two groups (Fig. 1).

Scatter plots showing the combinations of $\mathrm{V}_{\mathrm{T}}$ with PEEP, driving pressure, Ppeak, and respiratory rate in patients who developed versus patients who did not develop PPCs, between the spine and brain group, and in patients with low risk [ARISCAT < 26] vs. moderate-tohigh risk [ARISCAT $\geq 26$ ] are shown in Fig. 2, ESM Figures S2, S3.

\section{Occurrence of PPCs, intraoperative complications and outcomes}

Among the 784 patients included in the analysis, 81 (10.4\%) developed PPCs (Table 2). PPCs occurred mainly on day 3. No differences between the surgical groups were found as for probability of PPCs occurrence and hospital length of stay (ESM Figure S4).

Patients with ARISCAT $\geq 26$ showed an increased probability of PPCs occurrence compared to patients at lower risk (HR 2.50; 95\% CI 1.61-3.58, $p<0.000$ ), and of longer hospital length of stay (HR 0.81; 95\% CI 0.69.0.97, $p=0.019$ ) (ESM Figure S4).

Intraoperative episodes of hypotension and the need for vasoactive drugs during the procedure were frequent, especially in the spine group compared to the brain group $(38.7 \%$ vs $31.2 \%$ for hypotension; $p=0.028$ and $34.6 \%$ vs $27.7 \%$ for vasoactive drugs, $p=0.04$, 
Table 1 Pre-Operative Characteristics of the Patients According to Subgroups (Continued)

\begin{tabular}{|c|c|c|c|c|c|c|c|c|c|c|c|c|}
\hline & $\begin{array}{l}\text { All } \\
\text { Patients }\end{array}$ & Brain & Spine & $\begin{array}{l}p \\
\text { value }\end{array}$ & $\begin{array}{l}\text { All } \\
\text { patients }\end{array}$ & PPC & No PPC & $\begin{array}{l}p \\
\text { value }\end{array}$ & $\begin{array}{l}\text { All } \\
\text { patients }\end{array}$ & $\begin{array}{l}\text { ARISCAT }< \\
26\end{array}$ & $\begin{array}{l}\text { ARISCAT } \geq \\
26\end{array}$ & $\begin{array}{l}\boldsymbol{p} \\
\text { value }\end{array}$ \\
\hline RBC transfusion $(<24 h)$ & $28(3.6)$ & $16(4.3)$ & $12(2.9)$ & 0.589 & $5(0.6)$ & $1(1.2)$ & $4(0.6)$ & 0.722 & $1(0.2)$ & $4(2.0)$ & $5(0.7)$ & 0.007 \\
\hline Respiratory infection $(<$ & $1(0.1)$ & $0(0.0)$ & $1(0.2)$ & 0.322 & $28(3.6)$ & $3(3.7)$ & $25(3.6)$ & 0.002 & $7(1.3)$ & $19(9.5)$ & $26(3.5)$ & 0.000 \\
\hline
\end{tabular}

30d), n (\%)

\section{Laboratory tests and vital signs}

Pre-operative values

\begin{tabular}{|c|c|c|c|c|c|c|c|c|c|c|c|c|}
\hline $\mathrm{SpO}_{2}, \%$, median (IQR) & $\begin{array}{l}97(96 ; \\
99)\end{array}$ & $\begin{array}{l}97(96 ; \\
98)\end{array}$ & $\begin{array}{l}97(96 ; \\
99)\end{array}$ & 0.230 & $\begin{array}{l}97(96 ; \\
99)\end{array}$ & $\begin{array}{l}97(95 ; \\
98)\end{array}$ & $\begin{array}{l}98(96 ; \\
99)\end{array}$ & 0.002 & $\begin{array}{l}98(96 ; \\
99)\end{array}$ & $96(94 ; 98)$ & $97(96 ; 99)$ & 0.000 \\
\hline $\mathrm{Hb},(\mathrm{g} / \mathrm{dL})$, mean $(\mathrm{SD})$ & $13.8(1.8)$ & $13.8(1.8)$ & $13.9(1.8)$ & 0.540 & $13.8(1.8)$ & $13.7(2.0)$ & $13.8(1.8)$ & 0.442 & $14.0(1.6)$ & $13.3(2.1)$ & $13.8(1.8)$ & .000 \\
\hline $\begin{array}{l}\left.\text { WBC, (cell/mm } / \mathrm{mm}^{3}\right) \text {, mean } \\
\text { (SD) }\end{array}$ & $\begin{array}{l}7879 \\
(3497)\end{array}$ & $\begin{array}{l}8199 \\
(3097)\end{array}$ & $\begin{array}{l}7568 \\
(3825)\end{array}$ & 0.019 & $\begin{array}{l}7891 \\
(3503)\end{array}$ & $\begin{array}{l}9261 \\
(6168)\end{array}$ & $\begin{array}{l}7721 \\
(2978)\end{array}$ & 0.000 & $\begin{array}{l}7696 \\
(3362)\end{array}$ & $\begin{array}{l}8438 \\
(3845)\end{array}$ & $\begin{array}{l}7905 \\
(3518)\end{array}$ & 0.015 \\
\hline $\begin{array}{l}\text { eatinine, }(\mathrm{mg} / \mathrm{dL}) \text {, } \\
\text { ean (SD) }\end{array}$ & $\begin{array}{l}0.89 \\
(0.69)\end{array}$ & $\begin{array}{l}0.90 \\
(0.86)\end{array}$ & $\begin{array}{l}0.88 \\
(0.49)\end{array}$ & 0.758 & $\begin{array}{l}0.89 \\
(0.69)\end{array}$ & $\begin{array}{l}0.87 \\
(0.28)\end{array}$ & $\begin{array}{l}0.90 \\
(0.73)\end{array}$ & 0.722 & $\begin{array}{l}0.87 \\
(0.59)\end{array}$ & $0.95(0.91)$ & $0.89(0.70)$ & \\
\hline
\end{tabular}

\section{Surgical characteristics}

Condition, n (\%)

Elective
Urgency
Emergency

Planned duration, hours, $\mathrm{n}(\%)$

$\begin{array}{llll}0 & 1(0.1) & 1(0.3) & 0(0.0) \\ \leq 2 & 432 & 186 & 246 \\ & (55.1) & (49.5) & (60.3) \\ 2-3 & 201 & 90(23.9) & 111 \\ & (25.6) & & (27.2) \\ >3 & 150 & 99(26.3) & 51(12.5) \\ & (19.1) & & \\ \text { Antibiotic prophylaxis, } n & 711 & 338 & 373\end{array}$

(\%)

(90.9) (90.1) (91.6)

$\begin{array}{lll}717 & 338 & 379 \\ (91.5) & (89.9) & (92.9) \\ 50(6.4) & 28(7.4) & 22(5.4) \\ 17(2.2) & 10(2.7) & 7(1.7)\end{array}$

$\begin{array}{ll}0.318 & 0.140\end{array}$

0.000

\section{2}

(91.6)

$73(90.1) \quad 639$

$49(6.3)-4(4.9)-45(6.5)$

$16(2.1) \quad 4(4.9) \quad 12(1.7)$

0.000

$1(0.1) \quad 0(0.0) \quad 1(0.1)$

$426 \quad 36(44.4) \quad 390$

$(54.8) \quad(56.0)$

$201 \quad 15(18.5) \quad 186$

(25.9) (26.7)

$149 \quad 30(37.0) \quad 119$

(19.2) (17.1)

$0.462 \quad 705$

$74(91.4) \quad 631$

(91.0)
$513 \quad 172(86.0) \quad 685(91.6)$

(93.6)

$31(5.7) \quad 16(8.0) \quad 47(6.3)$

$4(0.7) \quad 12(6.0) \quad 16(2.1)$

0.000

0.000

(90.9)

\begin{tabular}{|c|c|c|c|c|}
\hline & $\begin{array}{l}378 \\
(69.0)\end{array}$ & $25(12.5)$ & 403 (53.9) & \\
\hline & $\begin{array}{l}124 \\
(22.6)\end{array}$ & $73(36.5)$ & $197(26.3)$ & \\
\hline & $46(8.4)$ & $102(51.0)$ & 148 (19.8) & \\
\hline 0.897 & $\begin{array}{l}500 \\
(91.4)\end{array}$ & $184(92.0)$ & 684 (91.6) & 0.796 \\
\hline
\end{tabular}

$P$ value refers to the between-groups with Fisher-Freeman-Halton Exact test, Mann Whitney u-test, or Kruskal Wallis test, as appropriate. $N$ Number, IQR Interquartile range, SD Standard deviation, $h$ Hours, $d$ Days, PPC Postoperative pulmonary complications, COPD Chronic obstructive pulmonary disease, ASA American society of anesthesiologists, $\mathrm{RBC}$ Blood red cells, $\mathrm{SpO}_{2}$ Blood oxygen saturation, $\mathrm{Hb}$ Hemoglobin, WBC White blood cells

respectively) (Table 3 ). The incidence of desaturation was less frequent than hypotension or need of vasoactive drugs. No differences were found in terms of mortality or hospital length of stay in patients who developed and did not develop PPCs or the type of surgery. Patients with ARISCAT $\geq 26$ compared to those with ARISCAT< 26 , had longer LOS and higher hospital mortality (Table $3)$.

\section{Risk factors for PPCs}

Multivariable logistic regression was used to identify the predictors of PPCs. Duration of anaesthesia was independently associated for the development of PPCs. Analysing the predictors for type of neurosurgery, for age we found a significantly effect in the brain group (the omnibus $p$-value for the neurosurgery-age interaction was $p=0.031$ ), but not in the spine group. (Table ESM S7, ESM Figure S5, Fig. 3). The effect of age on PPC in the brain group was significant at age above 62 (ESM Figure S5).

\section{Discussion}

Our results show that: 1) Neurosurgical patients are ventilated with low $\mathrm{V}_{\mathrm{T}}$ and low PEEP levels, while recruitment manoeuvres are seldom applied. No clinically significant differences exist between the intraoperative ventilator settings and the incidence of PPCs between the subgroups analysed, and in patients undergoing brain and spine surgery. $\mathrm{ETCO}_{2}$ levels are generally medium-low, especially in the brain surgery group; 2) PPCs are common, with similar incidence in the spineand the brain surgical groups; 3 ) Intraoperative complications occur in a large number of patients (44\% of the total population); of these, hypotension and the need for vasopressors are common; 4) Increasing age (for the brain group) and long surgical procedures are independently associated with development of PPCs. 
Table 2 Intra-Operative Characteristics of the Patients According to Subgroups

\begin{tabular}{|c|c|c|c|c|c|c|c|c|c|c|c|c|}
\hline & All Patients & Brain & Spine & $\begin{array}{l}p \\
\text { value }\end{array}$ & All patients & PPC & No PPC & $\begin{array}{l}p \\
\text { value }\end{array}$ & All patients & $\begin{array}{l}\text { ARISCAT } \\
<26\end{array}$ & $\begin{array}{l}\text { ARISCAT } \\
\geq 26\end{array}$ & $\begin{array}{l}p \\
\text { value }\end{array}$ \\
\hline$n(\%)$ & $784(100.0)$ & $376(48.0)$ & $408(52.0)$ & & $777(100.0)$ & $81(10.4)$ & $696(89.6)$ & & $748(100.0)$ & $548(73.3)$ & $200(26.7)$ & \\
\hline \multicolumn{13}{|c|}{ Ventilation and vital signs } \\
\hline $\begin{array}{l}\text { Ventilatory mode, } \mathrm{n} \\
(\%)\end{array}$ & & & & 0.000 & & & & 0.376 & & & & 0.452 \\
\hline Volume controlled & $494(63.8)$ & $259(70.2)$ & $235(58.0)$ & & $488(63.5)$ & $50(64.1)$ & $438(63.5)$ & & $467(63.2)$ & $341(62.9)$ & $126(64.0)$ & \\
\hline $\begin{array}{l}\text { Pressure } \\
\text { controlled }\end{array}$ & $149(19.3)$ & $42(11.4)$ & $107(26.4)$ & & $149(19.4)$ & $20(25.6)$ & $129(18.7)$ & & $146(19.8)$ & $112(20.7)$ & $34(17.3)$ & \\
\hline Pressure support & $3(0.4)$ & $2(0.5)$ & $1(0.2)$ & & $3(0.4)$ & $0(0.0)$ & $3(0.4)$ & & $3(0.4)$ & $1(0.2)$ & $2(1.0)$ & \\
\hline Spontaneous & $64(8.3)$ & $21(5.7)$ & $43(10.6)$ & & $64(8.3)$ & $4(5.1)$ & $60(8.7)$ & & $60(8.1)$ & $42(7.7)$ & $18(9.1)$ & \\
\hline Other & $64(8.3)$ & $45(12.2)$ & $19(4.7)$ & & $64(8.3)$ & $4(5.1)$ & $60(8.7)$ & & $63(8.5)$ & $46(8.5)$ & $17(8.6)$ & \\
\hline $\mathrm{V}_{T}, \mathrm{ml}$, median (IQR) & $\begin{array}{l}510(475 ; \\
575)\end{array}$ & $\begin{array}{l}511(475 \\
584)\end{array}$ & $\begin{array}{l}506(471 ; \\
562)\end{array}$ & 0.183 & $\begin{array}{l}510(475 ; \\
575)\end{array}$ & $\begin{array}{l}500(458 ; \\
560)\end{array}$ & $\begin{array}{l}513(475 \\
575)\end{array}$ & 0.096 & $\begin{array}{l}510(475 ; \\
572)\end{array}$ & $\begin{array}{l}506(475 \\
565)\end{array}$ & $\begin{array}{l}525(480 ; \\
590)\end{array}$ & 0.142 \\
\hline $\begin{array}{l}\mathrm{V}_{\mathrm{T}}(\mathrm{ml} / \mathrm{kg} \mathrm{PBW}) \\
\text { median (IQR) }\end{array}$ & $8.0(7.3 ; 9.0)$ & $8.2(7.3 ; 9.1)$ & $8.0(7.2 ; 8.9)$ & 0.150 & $8.0(7.3 ; 9.0)$ & $7.7(7.0 ; 8.8)$ & $8.1(7.3 ; 9.0)$ & 0.060 & $8.0(7.3 ; 9.0)$ & $8.0(7.3 ; 9.0)$ & $8.0(7.3 ; 9.1)$ & 0.420 \\
\hline $\begin{array}{l}\text { PPeak, } \mathrm{CmH}_{2} \mathrm{O} \text {, } \\
\text { median (IQR) }\end{array}$ & $18(15 ; 21)$ & $18(15 ; 21)$ & $18(16 ; 21)$ & 0.225 & $18(15 ; 21)$ & $18(16 ; 21)$ & $18(15 ; 21)$ & 0.183 & $18(15 ; 21)$ & $18(15 ; 21)$ & $18(16 ; 21)$ & 0.061 \\
\hline $\begin{array}{l}\text { PPlateau, } \mathrm{CmH}_{2} \mathrm{O} \text {, } \\
\text { median (IQR) }\end{array}$ & $16(14 ; 19)$ & $16(14 ; 19)$ & $16(14 ; 18)$ & 0.201 & $16(14 ; 19)$ & $17(14 ; 19)$ & $16(14 ; 19)$ & 0.150 & $16(14 ; 19)$ & $16(14 ; 18)$ & $17(15 ; 19)$ & 0.012 \\
\hline $\begin{array}{l}\mathrm{PEEP}, \mathrm{CmH}_{2} \mathrm{O} \text {, } \\
\text { median (IQR) }\end{array}$ & $5.0(3.0 ; 5.0)$ & $5.0(4.0 ; 5.0)$ & $5.0(3.0 ; 5.0)$ & 0.669 & $5.0(3.0 ; 5.0)$ & $5.0(4.0 ; 5.0)$ & $5.0(3.0 ; 5.0)$ & 0.225 & $5.0(3.0 ; 5.0)$ & $5.0(3.0 ; 5.0)$ & $5.0(3.3 ; 5.0)$ & 0.156 \\
\hline $\begin{array}{l}\mathrm{DP}, \mathrm{cmH}_{2} \mathrm{O} \text {, median } \\
\text { (IQR) }\end{array}$ & $12(11 ; 15)$ & $13(11 ; 15)$ & $12(10 ; 16)$ & 0.585 & $12(11 ; 15)$ & $13(11 ; 15)$ & $12(11 ; 15)$ & 0.201 & $12(11 ; 15)$ & $12(11 ; 15)$ & $14(11 ; 17)$ & 0.009 \\
\hline $\mathrm{RR}$, bpm, mean (SD) & $12.0(1.5)$ & $12.1(1.5)$ & $12.0(1.4)$ & 0.237 & $12.0(1.5)$ & $12.1(1.7)$ & $12.0(1.4)$ & 0.669 & $12.0(1.4)$ & $12.1(1.3)$ & $11.9(1.7)$ & 0.188 \\
\hline $\mathrm{FiO}_{2}, \%$, median (IQR) & $50(43 ; 65)$ & $50(40 ; 60)$ & $50(44 ; 68)$ & 0.021 & $50(43 ; 64)$ & $50(46 ; 65)$ & $50(42 ; 63)$ & 0.585 & $50(43 ; 65)$ & $50(43 ; 70)$ & $50(45 ; 60)$ & 0.143 \\
\hline $\begin{array}{l}\mathrm{SpO}_{2}, \% \text {, median } \\
\text { (IQR) }\end{array}$ & $99(98 ; 100)$ & $99(99 ; 100)$ & $99(98 ; 100)$ & 0.169 & $99(98 ; 100)$ & $99(98 ; 100)$ & $99(98 ; 100)$ & 0.237 & $99(98 ; 100)$ & $99(99 ; 100)$ & $99(98 ; 100)$ & 0.069 \\
\hline $\begin{array}{l}\mathrm{ETCO}_{2}, \mathrm{mmHg} \text {, mean } \\
\text { (SD) }\end{array}$ & $33(4)$ & $32(4)$ & $33(5)$ & 0.001 & $33(4)$ & $33(4)$ & $33(5)$ & 0.554 & $33(4)$ & $33(4)$ & $33(5)$ & 0.549 \\
\hline $\begin{array}{l}\text { MP, J/min, median } \\
\text { (IQR) }\end{array}$ & $6.6(4.9 ; 9.2)$ & $\begin{array}{l}6.9(5.0 \\
10.3)\end{array}$ & $6.2(4.8 ; 7.8)$ & 0.058 & $6.6(4.9 ; 9.2)$ & $\begin{array}{l}6.1(4.8 ; \\
10.5)\end{array}$ & $6.6(4.9 ; 9.1)$ & 0.856 & $6.6(4.9 ; 9.3)$ & $6.6(4.9 ; 8.6)$ & $\begin{array}{l}6.7(5.1 ; \\
10.8)\end{array}$ & 0.230 \\
\hline $\begin{array}{l}\text { MAP, mmHg, mean } \\
\text { (SD) }\end{array}$ & $80(12)$ & $79(12)$ & $80(13)$ & 0.083 & $79(12)$ & $78(11)$ & $80(13)$ & 0.021 & $79(12)$ & 79 (12) & $80(13)$ & 0.212 \\
\hline $\begin{array}{l}\text { Heart rate, bpm, } \\
\text { mean (SD) }\end{array}$ & $71(12)$ & $69(12)$ & $72(12)$ & 0.004 & $71(12)$ & $68(12)$ & $71(12)$ & 0.169 & $70(12)$ & $71(12)$ & $70(13)$ & 0.355 \\
\hline RM, $n(\%)$ & $54(6.9)$ & $29(7.8)$ & $25(6.1)$ & 0.365 & $54(6.9)$ & $29(7.8)$ & $25(6.1)$ & 0.365 & $51(6.8)$ & $36(6.6)$ & $15(7.5)$ & 0.664 \\
\hline \multicolumn{13}{|c|}{ Anesthesia characteristics } \\
\hline \multicolumn{13}{|l|}{ Opioids, n (\%) } \\
\hline No & $2(0.3)$ & $0(0.0)$ & $2(0.5)$ & & $2(0.3)$ & $0(0.0)$ & $2(0.5)$ & & $90(12.0)$ & $65(11.9)$ & $25(12.5)$ & \\
\hline Yes & $782(99.7)$ & $376(100.0)$ & $406(99.5)$ & 0.174 & $782(99.7)$ & $376(100.0)$ & $406(99.5)$ & 0.629 & $746(99.7)$ & $546(99.6)$ & $200(100.0)$ & 0.392 \\
\hline Opioids type, n (\%) & & & & 0.000 & & & & 0.055 & & & & 0.836 \\
\hline Short acting & $221(28.2)$ & $137(36.4)$ & $84(20.6)$ & & $220(28.3)$ & $20(24.7)$ & $200(28.7)$ & & $2(0.3)$ & $2(0.4)$ & $0(0.0)$ & \\
\hline Long acting & $466(59.4)$ & $189(50.3)$ & $277(67.9)$ & & $460(59.2)$ & $43(53.1)$ & $417(59.9)$ & & $212(28.3)$ & $154(28.1)$ & $58(29.0)$ & \\
\hline $\begin{array}{l}\text { Total fluids, ml, } \\
\text { median (IQR) }\end{array}$ & $\begin{array}{l}1500(1000 ; \\
2000)\end{array}$ & $\begin{array}{l}1500(1000 ; \\
2000)\end{array}$ & $\begin{array}{l}1500(1000 ; \\
2000)\end{array}$ & 0.022 & $\begin{array}{l}1500(1000 ; \\
2000)\end{array}$ & $\begin{array}{l}1800(1200 ; \\
2125)\end{array}$ & $\begin{array}{l}1500(1000 ; \\
2000)\end{array}$ & 0.001 & $\begin{array}{l}1500(1000 ; \\
2000)\end{array}$ & $\begin{array}{l}1300 \text { (1000; } \\
2000)\end{array}$ & $\begin{array}{l}2000(1100 ; \\
3000)\end{array}$ & 0.000 \\
\hline Cristalloids & $\begin{array}{l}1175(1000 ; \\
2000)\end{array}$ & $\begin{array}{l}1200(1000 ; \\
2000)\end{array}$ & $\begin{array}{l}1000(1000 ; \\
1500)\end{array}$ & 0.012 & $\begin{array}{l}1200(1000 ; \\
2000)\end{array}$ & $\begin{array}{l}1500(1000 ; \\
2050)\end{array}$ & $\begin{array}{l}1000(1000 ; \\
2000)\end{array}$ & 0.000 & $\begin{array}{l}1200 \text { (1000; } \\
2000)\end{array}$ & $\begin{array}{l}1000(1000 ; \\
1500)\end{array}$ & $\begin{array}{l}1725(1000 ; \\
2475)\end{array}$ & 0.000 \\
\hline Colloids & $\begin{array}{l}0.0(0.0 ; \\
500.0)\end{array}$ & $\begin{array}{l}0.0(0.0 ; \\
500.0)\end{array}$ & $\begin{array}{l}0.0(0.0 ; \\
500.0)\end{array}$ & 0.649 & $\begin{array}{l}0.0(0.0 ; \\
500.0)\end{array}$ & $\begin{array}{l}0.0(0.0 ; \\
500.0)\end{array}$ & $\begin{array}{l}0.0(0.0 ; \\
500.0)\end{array}$ & 0.719 & $\begin{array}{l}0.0(0.0 ; \\
500.0)\end{array}$ & $\begin{array}{l}0.0(0.0 ; \\
125.0)\end{array}$ & $\begin{array}{l}0.0(0.0 ; \\
500.0)\end{array}$ & 0.649 \\
\hline
\end{tabular}

$P$-value refers to the between-groups difference with Fisher-Freeman-Halton Exact test, Mann Whitney u-test, or Kruskal Wallis test, as appropriate. $N$ Number; IQR Interquartile range, SD Standard deviation, PPC Postoperative pulmonary complications, $P B W$ Predicted body weight, $V_{T}$ Tidal volume, PPeak Peak pressure, PPlateau Plateau pressure, PEEP Positive end-expiratory pressure, DP Driving pressure, $R R$ Respiratory rate, $\mathrm{FiO}_{2}$ Fraction of inspired oxygen, $\mathrm{SpO} \mathrm{O}_{2}$ Blood oxygen saturation, $E T \mathrm{CO}_{2}$ End-tidal carbon dioxide, MP Mechanical power, MAP Mean arterial pressure, $H R$ Heart rate, RM Recruitment maneuvers 


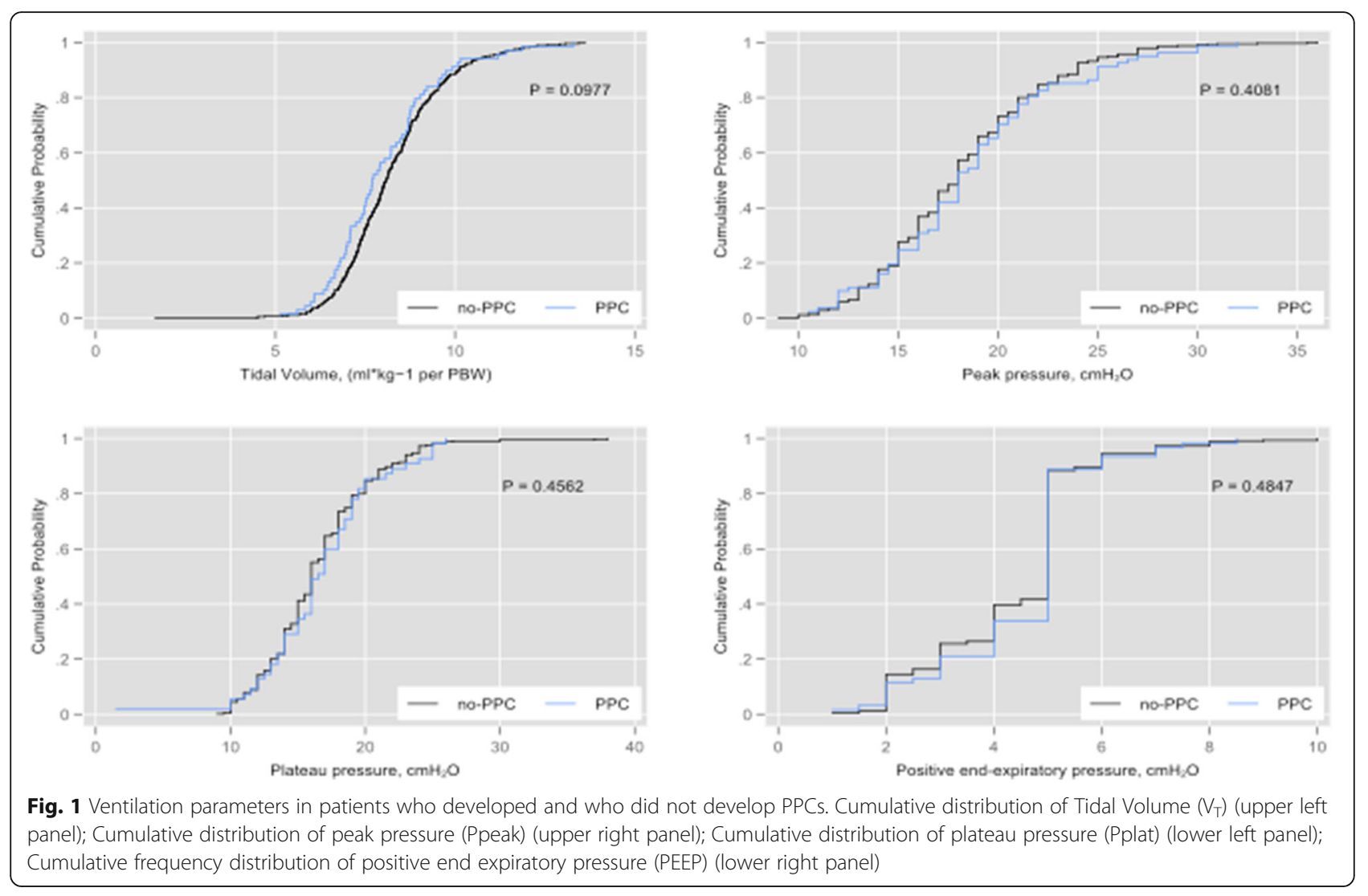

To our knowledge, this is the first prospective observational study in neurosurgical patients specifically focusing on the prevalence of PPCs and the effects of intraoperative mechanical ventilation settings on PPCs development. Our study is a sub-analysis of the LAS VEGAS study [10], a large international observational study describing the ventilator settings and PPCs occurrence in the perioperative period across different countries, and can therefore be considered representative for the current clinical practice in this population.

\section{Ventilator strategies in patients undergoing neurosurgical interventions}

Currently applied lung-protective ventilation strategies have shown to reduce PPCs [13, 14]. In patients undergoing spine surgery, the prone position has various effects on pulmonary function, including a decreased dynamic lung compliance and increased peak inspiratory pressure [13]; however, no large observational studies or randomized controlled trials are available regarding protective ventilator settings and their effect on PPCs in the prone position in non-ARDS patients.

In brain injured patients, lung-protective ventilation could be deleterious [7]; in particular, possible high intra-thoracic pressures when using high PEEP levels and permissive hypercapnia can have detrimental effects on cerebral perfusion pressure (CPP) and intracranial pressure (ICP). Therefore, brain injury patients are traditionally ventilated with tidal volumes approximating 9 $\mathrm{ml} / \mathrm{kg}$ of PBW [5]. However, recent studies suggest that high $V_{T}$ is a risk factor for acute lung injury even in patients with neurological disorders [4]. Indeed, our results suggest that the use of low $V_{T}$ is increasingly applied also in neurosurgical patients. Similarly, the application of PEEP in brain injured patients has been traditionally considered detrimental for ICP, by reducing venous outflow [15]. However, recent evidence demonstrates that PEEP application might not compromise ICP, provided that arterial blood pressure is preserved $[16,17]$.

In our cohort, neurosurgical patients were ventilated with low PEEP levels and no differences in PEEP levels were detected between the brain and spine groups. No data is available on the effects of RM in neurosurgical patients and their role within the intraoperative protective ventilation bundle remains unclear. In brain injured patients, RMs can have a dangerous effect on ICP by impairment of jugular blood outflow, and increase of intrathoracic pressure with impediment of cerebral venous return to the right atrium [8]. Although pressure-control recruitment manoeuvres improve oxygenation without impairing ICP or CPP, there is still concern regarding their application in neurosurgical patients, and therefore 

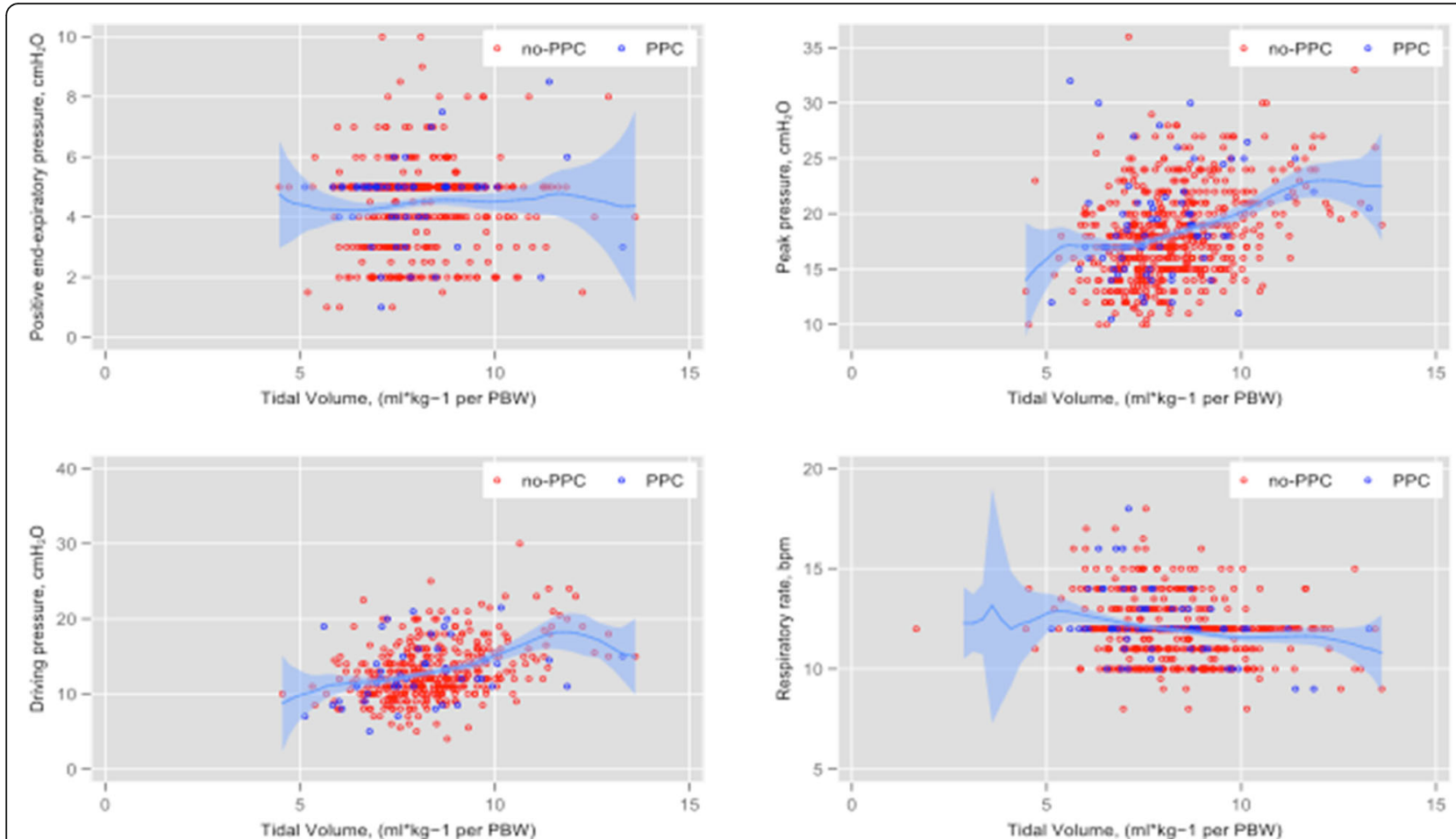

Fig. 2 Combinations of ventilator settings in patients who developed or not developed PPCs. Scatterplots showing distribution of tidal volume with positive end expiratory pressure combinations (upper left panel); tidal volume with Peak pressure (upper right panel); tidal volume with Driving pressure (lower left panel); tidal volume and respiratory rate (lower right panel). Scatter and the fitted line for each of the bivariate plots are shown in blue

are rarely performed [8]. Indeed, our results show that recruitment manoeuvres are seldom applied in neurosurgical patients.

To date, no clinical studies comparing pressurecontrolled ventilation (PCV) and VCV in brain injured patients are published. In obese [18], ARDS [19], and thoracic patients [20], research suggests no difference in outcome between the modes of ventilation (PCV and VCV). In a trial [21] including patients undergoing spinal surgery, PCV decreased intraoperative surgical bleeding compared with the VCV group $(p<0.001)$, possibly by lowering peak inspiratory pressures. A recent randomized controlled trial during lumbar spine surgery demonstrated that hemodynamic variables and arterial blood gas results did not differ significantly between the VCV and PCV with volume guaranteed (PCV-VG) mode groups [13]. Also, a recent large observational study suggested that $\mathrm{PCV}$ is associated with increase of PPC compared to VCV [22]. This association is not confirmed by our results. In our cohort, patients undergoing spinal surgery were more frequently ventilated with $\mathrm{VCV}$ than the brain injured group. However, despite the pathophysiological differences of prone vs supine ventilation, we did not find any other differences in the ventilator settings between the two groups.
In our cohort, $\mathrm{ETCO}_{2}$ levels were generally mediumlow, with significantly lower values in the brain surgery group compared to the spinal surgery group. This result suggests that patients undergoing brain surgery are more likely to be hyperventilated. This is most likely out of concern for potential increased intracranial pressure.

Although the subgroup with ARISCAT $\geq 26$ shows higher values of driving pressure and plateau pressure (plateau pressure (17 vs $\left.16 \mathrm{cmH}_{2} \mathrm{O}, p=0.012\right)$, and higher driving pressure (14 vs $12 \mathrm{cmH}_{2} \mathrm{O} ; p=0.009$ ), these values still remain within the recommended ranges for protective ventilation $[22,23]$. In general, in the whole population, a low total energy was applied to the respiratory system [23] (median mechanical power (6.2 $\mathrm{J} / \mathrm{min}$ )), with values which remain far from the threshold of $12 \mathrm{~J} / \mathrm{min}$ suggested as increased risk of lung injury [23].

\section{Post- operative pulmonary complications}

Clinical studies suggest that the application of protective ventilation can reduce PPCs $[24,25]$, with high $\mathrm{V}_{\mathrm{T}}$ identified as an independent predictor of PPCs development $[26,27]$. Trials in obese [27] and non-obese [28] patients undergoing abdominal surgery demonstrated that the intraoperative application of high level of PEEP and RMs 
Table 3 Outcomes According to Subgroups

\begin{tabular}{|c|c|c|c|c|c|c|c|c|c|c|c|c|}
\hline & $\begin{array}{l}\text { All } \\
\text { Patients }\end{array}$ & Brain & Spine & $\begin{array}{l}\boldsymbol{p} \\
\text { value }\end{array}$ & $\begin{array}{l}\text { All } \\
\text { patients }\end{array}$ & PPC & No PPC & $\begin{array}{l}p \\
\text { value }\end{array}$ & $\begin{array}{l}\text { All } \\
\text { patients }\end{array}$ & $\begin{array}{l}\text { ARISCAT }< \\
26\end{array}$ & $\begin{array}{l}\text { ARISCAT } \geq \\
26\end{array}$ & $\begin{array}{l}\boldsymbol{p} \\
\text { value }\end{array}$ \\
\hline$n(\%)$ & $\begin{array}{l}784 \\
(100.0)\end{array}$ & $\begin{array}{l}376 \\
(48.0)\end{array}$ & $\begin{array}{l}408 \\
(52.0)\end{array}$ & & $\begin{array}{l}777 \\
(100.0)\end{array}$ & $\begin{array}{l}81 \\
(10.4)\end{array}$ & $\begin{array}{l}696 \\
(89.6)\end{array}$ & & $\begin{array}{l}748 \\
(100.0)\end{array}$ & $548(73.3)$ & $200(26.7)$ & \\
\hline \multicolumn{13}{|l|}{ PPCs, n (\%) } \\
\hline PPCs & $81(10.4)$ & $\begin{array}{l}46 \\
(12.4)\end{array}$ & $35(8.6)$ & 0.085 & $\begin{array}{l}777 \\
(100.0)\end{array}$ & $\begin{array}{l}81 \\
(10.4)\end{array}$ & $\begin{array}{l}696 \\
(89.6)\end{array}$ & 0.000 & $80(10.8)$ & $43(7.9)$ & 37 (18.6) & 0.000 \\
\hline Need of oxygen & $69(8.9)$ & $\begin{array}{l}38 \\
(10.2)\end{array}$ & $31(7.6)$ & 0.202 & $81(10.4)$ & $\begin{array}{l}81 \\
(100.0)\end{array}$ & $0(0.0)$ & 0.000 & $68(9.2)$ & $39(7.2)$ & $29(14.6)$ & 0.002 \\
\hline Respiratory failure & $14(1.8)$ & $8(2.2)$ & $6(1.5)$ & 0.478 & $69(8.9)$ & $\begin{array}{l}69 \\
(85.2)\end{array}$ & $0(0.0)$ & 0.000 & $14(1.9)$ & $6(1.1)$ & $8(4.0)$ & 0.010 \\
\hline NIV & $9(1.2)$ & $4(1.2)$ & $5(1.2)$ & 0.963 & $14(1.8)$ & $\begin{array}{l}14 \\
(17.3)\end{array}$ & $0(0.0)$ & 0.000 & $9(1.3)$ & $7(1.3)$ & $2(1.1)$ & 0.801 \\
\hline ARDS & $1(0.1)$ & $1(0.3)$ & $0(0.0)$ & 0.295 & $9(1.2)$ & $5(6.3)$ & $4(0.6)$ & 0.003 & $1(0.1)$ & $0(0.0)$ & $1(0.5)$ & 0.098 \\
\hline Pneumothorax & $1(0.1)$ & $1(0.3)$ & $0(0.0)$ & 0.295 & $1(0.1)$ & $1(1.2)$ & $0(0.0)$ & 0.003 & $1(0.1)$ & $0(0.0)$ & $1(0.5)$ & 0.098 \\
\hline \multicolumn{13}{|l|}{ Secondary outcomes, n (\%) } \\
\hline Severe PPCS & $19(2.4)$ & $13(3.5)$ & $6(1.5)$ & 0.068 & $19(2.4)$ & $\begin{array}{l}19 \\
(23.5)\end{array}$ & $0(0.0)$ & 0.000 & $19(2.6)$ & $6(1.1)$ & $13(6.5)$ & 0.000 \\
\hline $\begin{array}{l}\text { Intra-operative } \\
\text { complications }\end{array}$ & $\begin{array}{l}344 \\
(43.9)\end{array}$ & $\begin{array}{l}154 \\
(41.1)\end{array}$ & $\begin{array}{l}190 \\
(46.6)\end{array}$ & 0.121 & $\begin{array}{l}342 \\
(44.1)\end{array}$ & $\begin{array}{l}46 \\
(56.8)\end{array}$ & $\begin{array}{l}296 \\
(42.6)\end{array}$ & 0.015 & $\begin{array}{l}336 \\
(44.9)\end{array}$ & $237(43.2)$ & $99(49.5)$ & 0.128 \\
\hline Desaturation & $38(4.9)$ & $23(6.1)$ & $15(3.7)$ & 0.110 & $37(4.8)$ & $\begin{array}{l}11 \\
(13.6)\end{array}$ & $26(3.7)$ & 0.000 & $36(4.8)$ & $21(3.8)$ & $15(7.5)$ & 0.038 \\
\hline Unplanned RMs & $25(3.2)$ & $15(4.0)$ & $10(2.5)$ & 0.220 & $24(3.1)$ & $5(6.2)$ & $19(2.7)$ & 0.091 & $22(2.9)$ & $12(2.2)$ & $10(5.0)$ & 0.043 \\
\hline Pressure reduction & $25(3.2)$ & $11(2.9)$ & $14(3.4)$ & 0.692 & $25(3.2)$ & $3(3.7)$ & $22(3.2)$ & 0.795 & $22(2.9)$ & $17(3.1)$ & $5(2.5)$ & 0.666 \\
\hline Flow limitation & $5(0.6)$ & $3(0.8)$ & $2(0.5)$ & 0.590 & $4(0.5)$ & $1(1.3)$ & $3(0.4)$ & 0.322 & $4(0.5)$ & $2(0.4)$ & $2(1.0)$ & 0.289 \\
\hline Hypotension & $\begin{array}{l}275 \\
(35.1)\end{array}$ & $\begin{array}{l}117 \\
(31.2)\end{array}$ & $\begin{array}{l}158 \\
(38.7)\end{array}$ & 0.028 & $\begin{array}{l}274 \\
(35.3)\end{array}$ & $\begin{array}{l}34 \\
(42.0)\end{array}$ & $\begin{array}{l}240 \\
(34.5)\end{array}$ & 0.185 & $\begin{array}{l}270 \\
(36.1)\end{array}$ & 197 (35.9) & $73(36.5)$ & 0.890 \\
\hline Vasopressors & $\begin{array}{l}245 \\
(31.3)\end{array}$ & $\begin{array}{l}104 \\
(27.7)\end{array}$ & $\begin{array}{l}141 \\
(34.6)\end{array}$ & 0.040 & $\begin{array}{l}244 \\
(31.4)\end{array}$ & $\begin{array}{l}37 \\
(45.7)\end{array}$ & $\begin{array}{l}207 \\
(29.8)\end{array}$ & 0.004 & $\begin{array}{l}242 \\
(32.4)\end{array}$ & 168 (30.7) & $74(37.0)$ & 0.101 \\
\hline New arrhythmias & $9(1.1)$ & $6(1.6)$ & $3(0.7)$ & 0.257 & $9(1.2)$ & $0(0.0)$ & $9(1.3)$ & 0.303 & $9(1.2)$ & $5(0.9)$ & $4(2.0)$ & 0.227 \\
\hline $\begin{array}{l}\text { Hospital LOS, days, median } \\
\text { (IQR) }\end{array}$ & $2(1 ; 5)$ & $2(1 ; 5)$ & $2(1 ; 5)$ & 0.993 & $2(1 ; 5)$ & $3(1 ; 5)$ & $2(1 ; 5)$ & 0.447 & $2(1 ; 5)$ & $2(1 ; 5)$ & $3(1 ; 5)$ & 0.033 \\
\hline Hospital mortality & $5(0.7)$ & $4(1.2)$ & $1(0.3)$ & 0.145 & $5(0.7)$ & $1(1.3)$ & $4(0.6)$ & 0.500 & $5(0.7)$ & $1(0.2)$ & $4(2.2)$ & 0.006 \\
\hline
\end{tabular}

did not reduce PPCs, when compared with lower PEEP level without RMs.

In our neurosurgical population, $10.3 \%$ of patients developed PPCs, similar to the results from the whole population of the LAS VEGAS [8]. No clinically significant differences exist in the incidence of PPCs when comparing the different intraoperative ventilator settings in the subgroups analysed.

Patients who developed PPCs had worse preoperative conditions (age, ARISCAT score, ASA status), longer duration of anaesthesia (thus suggesting a more complicated surgical procedure), intraoperative complications (in particular hypotension) and the administration of higher volumes of fluid. This latter point is of extreme importance as cerebral and spinal perfusion pressures are generally maintained by the administration of vasopressors and a large amount of fluids; however, a positive fluid balance can increase the risk for pulmonary damage and complications [28]. Finally, increasing age in the brain surgical group was associated with PPCs occurrence, thus making preoperative assessment extremely important in the management of this group of patients in order to optimize hospital resources and empathetically begin discussions with patients and their carers.

\section{Intraoperative complications and outcomes}

In our cohort, intraoperative complications occurred in a large number of patients $(44 \%$ of our total population). Moreover, we found an increased prevalence of intraoperative hemodynamic deterioration as compared to respiratory impairment in the intraoperative settings. According to our results, patients undergoing 

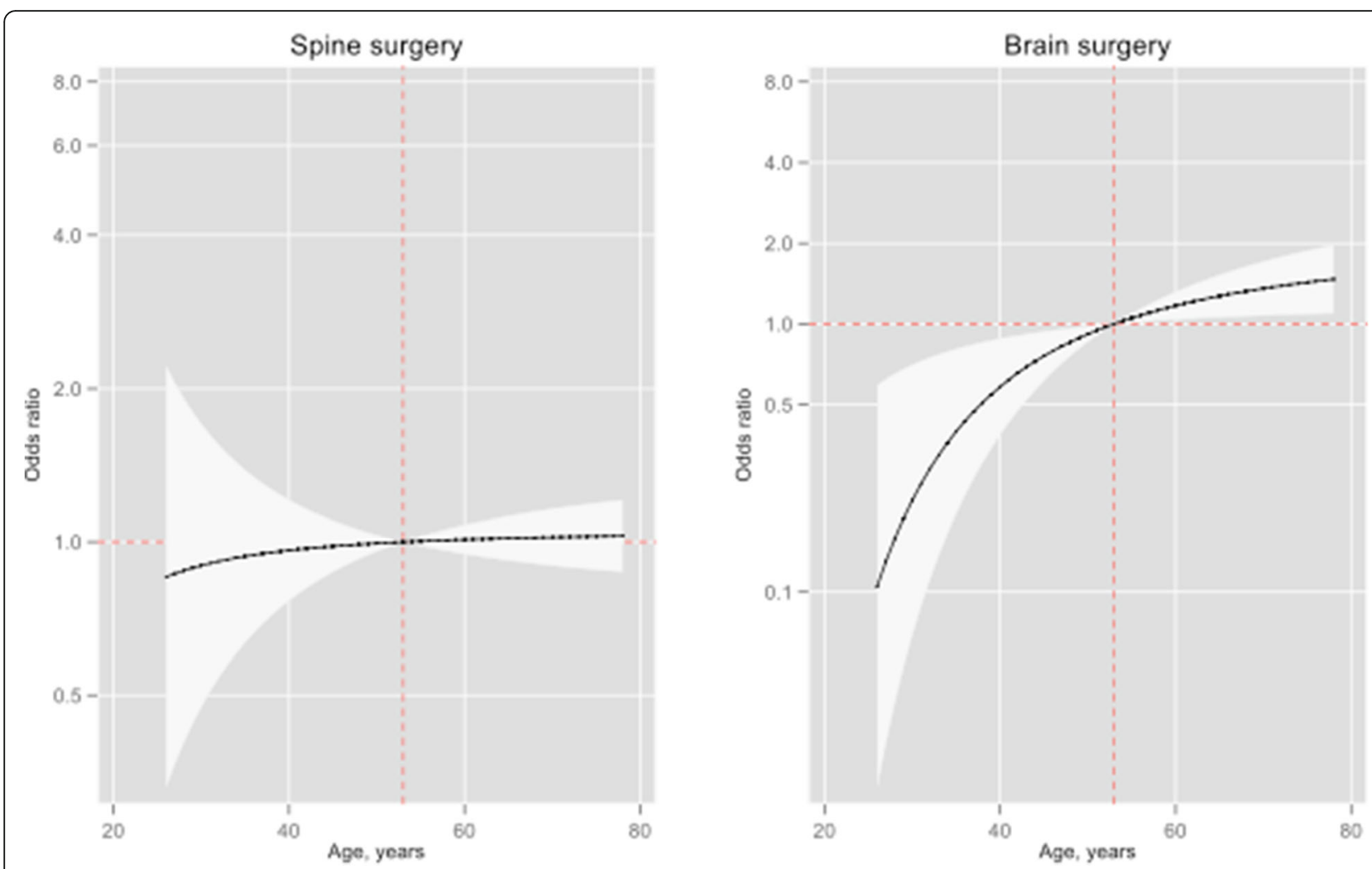

Fig. 3 Interaction between type of neurosurgery and age continuous on PPC as outcome. Odds ratio (per 1-unit change in age) is depicted along the continuum of age (years) with its median (53 years) as reference point. Analysis adjusted by duration of anaesthesia, desaturation, and ARISCAT risk score. Indeed, the prognostic effect of age on PPC varies according to neurosurgery subpopulations, with no effect on the spine group, and a significant crescendo effect on the brain group as patient aged

spine surgery have commonly episodes of intraoperative hypotension requiring the use of vasoactive drugs, probably related to the effects of prone position on cardiac function, including a decreased cardiac index [13].

Our results suggest that in neurosurgical patients, the most common intraoperative complications are related to hemodynamic rather than respiratory function. The fact that hypotension and hemodynamic impairment are common might suggest that limited levels of PEEP could be beneficial in this type of patients by having less negative impact on hemodynamic. These results are in accordance with recently published literature $[24,29]$, suggesting that the use of high PEEP can negatively impact the hemodynamic system, thus challenging the traditional concept of "open lung approach", and avoiding repeated alveolar collapse and expansion and keeping the lung partially at rest [30].

\section{Limitations}

Several limitations need to be mentioned. First, the manuscript derives from a secondary analysis from the LAS VEGAS study. Thus, the results represent an observation of associations and do not allow to draw causality conclusions, considering that there exist unaccounted confounding factors.

Second, this is an unplanned secondary analysis from the main study, and even though we built a meticulous statistical model, there could still be confounding factors affecting our results.

Third, as the design of the original study focused on intraoperative settings and variables in the general population, limited information was available regarding specific perioperative data in neurosurgical patients, in particular on the use neuro-monitoring and type of brain and spine surgery.

\section{Conclusions}

The main findings of this study are that MV settings in neurosurgical patients are characterized by low $\mathrm{V}_{\mathrm{T}}$ and low PEEP with seldom use of RMs. PPCs are frequent in this population and not associated with intraoperative ventilator setting. Further studies are warranted to assess the effect of ventilation strategies on the outcome of this cohort of patients. 


\section{Supplementary information}

Supplementary information accompanies this paper at https://doi.org/10. 1186/s12871-020-00988-x.

\section{Additional file 1.}

\section{Abbreviations}

$V_{\text {T: }}$ Tidal volume; Pplat: Plateau pressure; PEEP: Positive end-expiratory pressure; RM: Recruitment manoeuvres; PBW: Predicted body weight; PPCs: Postoperative pulmonary complications; ESM: Electronic supplemental material; Ppeak: Peak pressure; RR: Respiratory rate; $\mathrm{FiO}_{2}$ : Fraction of inspired oxygen; $\mathrm{ETCO}_{2}$ : End-tidal carbon dioxide; $\mathrm{SpO}_{2}$ : Peripheral saturation of oxygen; MP: Mechanical power; ASA: American Society of Anaesthesiologists; ARISCAT: Assess Respiratory Risk in Surgical Patients in Catalonia; VCV: Volume-controlled ventilation; IQR: Interquartile range; SD: Standard deviation; PCV: Pressure-controlled ventilation; LOS: Length of stay; CPP: Cerebral perfusion pressure; ICP: Intracranial pressure

\section{Acknowledgements}

We would like to acknowledge the medical and nursing staff of the operating rooms involved for their support in the completion of this study. Contributors

Las Vegas Investigators:

Austria

LKH Graz, Graz: Wolfgang Kroell, Helfried Metzler, Gerd Struber, Thomas

Wegscheider

AKH Linz, Linz: Hans Gombotz

Medical University Vienna: Michael Hiesmayr, Werner Schmid, Bernhard

Urbanek

Belgium

UCL - Cliniques Universitaires Saint Luc Brussels: David Kahn, Mona Momeni, Audrey Pospiech, Fernande Lois, Patrice Forget, Irina Grosu

Universitary Hospital Brussels (UZ Brussel): Jan Poelaert, Veerle van

Mossevelde, Marie-Claire van Malderen

Het Ziekenhuis Oost Limburg (ZOL), Genk: Dimitri Dylst, Jeroen van Melkebeek, Maud Beran

Ghent University Hospital, Gent: Stefan de Hert, Luc De Baerdemaeker, Bjorn Heyse, Jurgen Van Limmen, Piet Wyffels, Tom Jacobs, Nathalie Roels, Ann De Bruyne

Maria Middelares, Gent: Stijn van de Velde

European Society of Anaesthesiology, Brussels: Brigitte Leva, Sandrine Damster, Benoit Plichon

Bosnia and Herzegovina

General Hospital "prim Dr Abdulah Nakas" Sarajevo: Marina Juros-Zovko,

Dejana Djonović- Omanovic

Croatia

General Hospital Cakovec, Cakovec: Selma Pernar

General Hospital Karlovac, Karlovac: Josip Zunic, Petar Miskovic, Antonio Zilic

University Clinical Hospital Osijek, Osijek: Slavica Kvolik, Dubravka Ivic, Darija Azenic-Venzera, Sonja Skiljic, Hrvoje Vinkovic, Ivana Oputric University Hospital Rijeka, Rijeka: Kazimir Juricic, Vedran Frkovic

General Hospital Dr J Bencevic, Slavonski Brod: Jasminka Kopic, Ivan Mirkovic University Hospital Center Split, Split: Nenad Karanovic, Mladen Carev, Natasa Dropulic

University Hospital Merkur, Zagreb: Jadranka Pavicic Saric, Gorjana Erceg, Matea Bogdanovic Dvorscak

University Hospital Sveti Duh, Zagreb: Branka Mazul-Sunko, Anna Marija Pavicic, Tanja Goranovic

University Hospital, Medical school, "Sestre milosrdnice" (Sister of Charity),

Zagreb: Branka Maldini, Tomislav Radocaj, Zeljka Gavranovic, Inga MladicBatinica, Mirna Sehovic

Czech Republic

University Hospital Brno, Brno: Petr Stourac, Hana Harazim, Olga Smekalova Martina Kosinova, Tomas Kolacek, Kamil Hudacek, Michal Drab

University Hospital Hradec Kralove, Hradec Kralove: Jan Brujevic, Katerina

Vitkova, Katerina Jirmanova

University Hospital Ostrava, Ostrava: Ivana Volfova, Paula Dzurnakova Katarina Liskova

Nemocnice Znojmo, Znojmo: Radovan Dudas, Radek Filipsky
Egypt

El Sahel Teaching hospital, Cairo: Samir el Kafrawy

Kasr Al-Ainy Medical School, Cairo University: Hisham Hosny Abdelwahab, Tarek Metwally, Ahmed Abdel-Razek

Beni Sueif University Hospital, Giza: Ahmed Mostafa El-Shaarawy, Wael Fathy Hasan, Ahmed Gouda Ahmed

Fayoum University Hospital, Giza: Hany Yassin, Mohamed Magdy, Mahdy Abdelhady

Suis medical Insurance Hospital, Suis: Mohamed Mahran

Estonia

North Estonia Medical Center, Tallinn: Eiko Herodes, Peeter Kivik, Juri

Oganjan, Annika Aun

Tartu University Hospital, Tartu: Alar Sormus, Kaili Sarapuu, Merilin Mall, Juri

Karjagin

France

University Hospital of Clermont-Ferrand, Clermont-Ferrand: Emmanuel Futier, Antoine Petit, Adeline Gerard

Institut Hospitalier Franco-Britannique, Levallois-Perret: Emmanuel Marret, Marc Solier

Saint Eloi University Hospital, Montpellier: Samir Jaber, Albert Prades

Germany

Fachkrankenhaus Coswig, Coswig: Jens Krassler, Simone Merzky

University Hospital Carl Gustav Carus, Dresden: Marcel Gama de Abreu,

Christopher Uhlig,

Thomas Kiss, Anette Bundy, Thomas Bluth, Andreas Gueldner, Peter Spieth, Martin Scharffenberg, Denny Tran Thiem, Thea Koch

Duesseldorf University Hospital, Heinrich-Heine University: Tanja Treschan, Maximilian Schaefer

Bea Bastin, Johann Geib, Martin Weiss, Peter Kienbaum, Benedikt Pannen Diakoniekrankenhaus Friederikenstift, Hannover: Andre Gottschalk, Mirja Konrad, Diana Westerheide, Ben Schwerdtfeger

University of Leipzig, Leipzig: Hermann Wrigge, Philipp Simon, Andreas

Reske, Christian Nestler

Greece

"Alexandra" general hospital of Athens, Athens: Dimitrios Valsamidis,

Konstantinos Stroumpoulis

General air force hospital, Athens: Georgios Antholopoulos, Antonis

Andreou, Dimitris Karapanos

Aretaieion University Hospital, Athens: Kassiani Theodoraki, Georgios Gkiokas,

Marios-Konstantinos Tasoulis

Attikon University Hospital, Athens: Tatiana Sidiropoulou, Foteini

Zafeiropoulou, Panagiota Florou, Aggeliki Pandazi

Ahepa University Hospital Thessaloniki, Thessaloniki: Georgia Tsaousi,

Christos Nouris, Chryssa Pourzitaki,

Israel

The Lady Davis Carmel Medical Center, Haifa: Dmitri Bystritski, Reuven Pizov, Arieh Eden

Italy

Ospedale San. Paolo Bari, Bari: Caterina Valeria Pesce, Annamaria Campanile, Antonella Marrella

University of Bari "Aldo Moro", Bari: Salvatore Grasso, Michele De Michele Institute for Cancer Research and treatment, Candiolo, Turin: Francesco

Bona, Gianmarco Giacoletto, Elena Sardo

Azienda Ospedaliera per l'emergenza Cannizzaro, Catania: Luigi Giancarlo,

Vicari Sottosant

Ospedale Melegnano, Cernuso, Milano: Maurizio Solca

Azienda Ospedaliera - Universitaria Sant'Anna, Ferrara: Carlo Alberto Volta,

Savino Spadaro, Marco Verri, Riccardo Ragazzi, Roberto Zoppellari

Ospedali Riuniti Di Foggia - University of Foggia, Foggia: Gilda Cinnella,

Pasquale Raimondo, Daniela La Bella, Lucia Mirabella, Davide D'antini

IRCCS AOU San Martino IST Hospital, University of Genoa, Genoa: Paolo

Pelosi, Alexandre Molin, Iole Brunetti, Angelo Gratarola, Giulia Pellerano, Rosanna Sileo, Stefano Pezzatto, Luca Montagnani

IRCCS San Raffaele Scientific Institute, Milano: Laura Pasin, Giovanni Landoni,

Alberto Zangrillo, Luigi Beretta, Ambra Licia Di Parma, Valentina Tarzia,

Roberto Dossi, Marta Eugenia Sassone

Istituto europeo di oncologia - ieo, Milano: Daniele Sances, Stefano Tredici,

Gianluca Spano, Gianluca Castellani, Luigi Delunas, Sopio Peradze, Marco

Venturino

Ospedale Niguarda Ca'Granda Milano, Milano: Ines Arpino, Sara Sher 
Ospedale San Paolo - University of Milano, Milano: Concezione Tommasino, Francesca Rapido, Paola Morelli

University of Naples "Federico II" Naples: Maria Vargas, Giuseppe Servillo Policlinico "P. Giaccone", Palermo: Andrea Cortegiani, Santi Maurizio Raineri, Francesca Montalto, Vincenzo Russotto, Antonino Giarratano Azienda Ospedaliero-Universitaria, Parma: Marco Baciarello, Michela Generali, Giorgia Cerati

Santa Maria degli Angeli, Pordenone: Yigal Leykin

Ospedale Misericordia e Dolce - Us/4 Prato, Prato: Filippo Bressan, Vittoria Bartolini, Lucia Zamidei

University hospital of Sassari, Sassari: Luca Brazzi, Corrado Liperi, Gabriele Sales, Laura Pistidda

Insubria University, Varese: Paolo Severgnini, Elisa Brugnoni, Giuseppe

Musella, Alessandro Bacuzzi

Republic of Kosovo

Distric hospital Gjakova, Gjakove: Dalip Muhardr

University Clinical Center of Kosova, Prishtina: Agreta Gecaj-Gashi, Fatos Sada

Regional Hospital" Prim.Dr. Daut Mustafa", Prizren: Adem Bytyqi

Lithuania

Medical University Hospital, Hospital of Lithuanian University of Health

Sciences, Kaunas: Aurika Karbonskiene, Ruta Aukstakalniene, Zivile Teberaite, Erika Salciute

Vilnius University Hospital - Institute of Oncology, Vilnius: Renatas Tikuisis, Povilas Miliauskas

Vilnius University Hospital - Santariskiu Clinics, Vilnius: Sipylaite Jurate, Egle Kontrimaviciute, Gabija Tomkute

Malta

Mater Dei Hospital, Msida: John Xuereb, Maureen Bezzina, Francis Joseph Borg

Netherlands

Academic Medical Centre, University of Amsterdam: Sabrine Hemmes, Marcus Schultz, Markus Hollmann, Irene Wiersma, Jan Binnekade, Lieuwe Bos VU University Medical Center, Amsterdam: Christa Boer, Anne Duvekot MC Haaglanden, Den Haag: Bas in 't Veld, Alice Werger, Paul Dennesen, Charlotte Severijns

Westfriesgasthuis, Hoorn: Jasper De Jong, Jens Hering, Rienk van Beek Norway

Haukeland University Hospital, Bergen: Stefan Ivars, Ib Jammer

Førde Central Hospital /Førde Sentral Sykehus, Førde: Alena Breidablik

Martina Hansens Hospital, Gjettum: Katharina Skirstad Hodt, Frode Fjellanger,

Manuel Vico Avalos

Bærum Hospital, Vestre Viken, Rud: Jannicke Mellin-Olsen, Elisabeth

Andersson

Stavanger University Hospital, Stavanger: Amir Shafi-Kabiri

Panama

Hospital Santo Tomás, Panama: Ruby Molina, Stanley Wutai, Erick Morais Portugal

Hospital do Espírito Santo - Évora, E.P.E, Évora.: Glória Tareco, Daniel Ferreira, Joana Amaral

Centro Hospitalar de Lisboa Central, E.P.E, Lisboa:: Maria de Lurdes

Goncalves Castro, Susana Cadilha, Sofia Appleton

Centro Hospitalar de Lisboa Ocidental, E.P.E. Hospital de S. Francisco Xavier,

Lisboa: Suzana Parente, Mariana Correia, Diogo Martins

Santarem Hospital, Santarem: Angela Monteirosa, Ana Ricardo, Sara

Rodrigues

Romania

Spital Orasenesc, Bolintin Vale: Lucian Horhota

Clinical Emergency Hospital of Bucharest, Bucharest: Ioana Marina Grintescu, Liliana Mirea, loana Cristina Grintescu

Elias University Emergency Hospital, Bucharest: Dan Corneci, Silvius Negoita, Madalina Dutu, loana Popescu Garotescu

Emergency Institute of Cardiovascular Diseases Inst. "Prof. C. C. Iliescu",

Bucharest: Daniela Filipescu, Alexandru Bogdan Prodan

Fundeni Clinical institute - Anaesthesia and Intensive Care, Bucharest: Gabriela Droc, Ruxandra Fota, Mihai Popescu

Fundeni Clinical institute - Intensive Care Unit, Bucharest: Dana Tomescu, Ana Maria Petcu, Marian Irinel Tudoroiu

Hospital Profesor D Gerota, Bucharest: Alida Moise, Catalin-Traian Guran Constanta County Emergency Hospital, Constanta: Iorel Gherghina, Dan Costea, Iulia Cindea
University Emergency County Hospital Targu Mures, Targu Mures: SandaMaria Copotoiu, Ruxandra Copotoiu, Victoria Barsan, Zsolt Tolcser, Magda Riciu, Septimiu Gheorghe Moldovan, Mihaly Veres

Russia

Krasnoyarsk State Medical University, Krasnoyarsk: Alexey Gritsan, Tatyana Kapkan, Galina Gritsan, Oleg Korolkov

Burdenko Neurosurgery Institute, Moscow: Alexander Kulikov, Andrey Lubnin Moscow Regional Research Clinical Institute, Moscow: Alexey Ovezov, Pavel Prokoshev, Alexander Lugovoy, Natalia Anipchenko

Municipal Clinical Hospital 7, Moscow: Andrey Babayants, Irina Komissarova, Karginova Zalina

Reanimatology Research Institute n.a. Negovskij RAMS, Moscow: Valery

Likhvantsev, Sergei Fedorov

Serbia

Clinical Center of Vojvodina, Emergency Center, Novisad: Aleksandra Lazukic, Jasmina Pejakovic, Dunja Mihajlovic

Slovakia

National Cancer Institute, Bratislava: Zuzana Kusnierikova, Maria Zelinkova F.D. Roosevelt teaching Hospital, Banská Bystrica: Katarina Bruncakova, Lenka Polakovicova

Faculty Hospital Nové Zámky, Nové Zámky: Villiam Sobona

Slovenia

Institute of Oncology Ljubljana, Ljubljana: Barbka Novak-Supe, Ana PekleGolez, Miroljub Jovanov, Branka Strazisar

University Medical Centre Ljubljana, Ljubljana: Jasmina Markovic-Bozic, Vesna Novak-Jankovic, Minca Voje, Andriy Grynyuk, Ivan Kostadinov, Alenka

Spindler-Vese

Spain

Hospital Sant Pau, Barcelona: Victoria Moral, Mari Carmen Unzueta, Carlos

Puigbo, Josep Fava

Hospital Universitari Germans Trias I Pujol, Barcelona: Jaume Canet, Enrique Moret, Mónica Rodriguez Nunez, Mar Sendra, Andrea Brunelli, Frederic

Rodenas

University of Navarra, Pamplona: Pablo Monedero, Francisco Hidalgo Martinez, Maria Jose Yepes Temino, Antonio Martínez Simon, Ana de Abajo Larriba

Corporacion Sanitaria Parc Tauli, Sabadell: Alberto Lisi, Gisela Perez, Raquel Martinez

Consorcio Hospital General Universitario de Valencia, Valencia: Manuel

Granell, Jose Tatay Vivo, Cristina Saiz Ruiz, Jose Antonio de Andrés Ibañez Hospital Clinico Valencia, Valencia: Ernesto Pastor, Marina Soro, Carlos Ferrando, Mario Defez

Hospital Universitario Rio Hortega, Valladolid: Cesar Aldecoa AlvaresSantullano, Rocio Perez, Jesus Rico

Sweden

Central Hospital in Kristianstad: Monir Jawad, Yousif Saeed, Lars Gillberg Turkey

Ufuk University Hospital Ankara, Ankara: Zuleyha Kazak Bengisun, Baturay Kansu Kazbek

Akdeniz University Hospital, Antalya: Nesil Coskunfirat, Neval Boztug, Suat

Sanli, Murat Yilmaz, Necmiye Hadimioglu

Istanbul University, Istanbul medical faculty, Istanbul: Nuzhet Mert Senturk,

Emre Camci, Semra Kucukgoncu, Zerrin Sungur, Nukhet Sivrikoz

Acibadem University, Istanbul: Serpil Ustalar Ozgen, Fevzi Toraman

Maltepe University, Istanbul: Onur Selvi, Ozgur Senturk, Mine Yildiz

Dokuz Eylül Universitesi Tip Fakültesi, Izmir: Bahar Kuvaki, Ferim Gunenc,

Semih Kucukguclu, Sule Ozbilgin

Şifa University Hospital, Izmir: Jale Maral, Seyda Canli

Selcuk University faculty of medicine, Konya: Oguzhan Arun, Ali Saltali, Eyup Aydogan

Fatih Sultan Mehmet Eğitim Ve Araștirma Hastanesi, Istanbul: Fatma Nur

Akgun, Ceren Sanlikarip, Fatma Mine Karaman

Ukraine

Institute Of Surgery And Transplantology, Kiev: Andriy Mazur

Zaporizhzhia State Medical University, Zaporizhzhia: Sergiy Vorotyntsev

United Kingdom

SWARM Research Collaborative: for full list of SWARM contributors please see www.ukswarm.com

Northern Devon Healthcare NHS Trust, Barnstaple: Guy Rousseau, Colin Barrett, Lucia Stancombe 
Golden Jubilee National Hospital, Clydebank, Scotland: Ben Shelley, Helen Scholes

Darlington Memorial Hospital, County Durham and Darlington Foundation NHS Trust, Darlington: James Limb, Amir Rafi, Lisa Wayman, Jill Deane Royal Derby Hospital, Derby: David Rogerson, John Williams, Susan Yates, Elaine Rogers

Dorset County Hospital, Dorchester: Mark Pulletz, Sarah Moreton, Stephanie Jones

The Princess Alexandra NHS Hospital Trust, Essex: Suresh Venkatesh,

Maudrian Burton, Lucy Brown, Cait Goodall

Royal Devon and Exeter NHS Foundation Trust, Exeter: Matthew Rucklidge,

Debbie Fuller, Maria Nadolski, Sandeep Kusre

Hospital James Paget University Hospital NHS Foundation Trust, Great

Yarmouth: Michael Lundberg, Lynn Everett, Helen Nutt

Royal Surrey County Hospital NHS Foundation Trust, Guildford: Maka Zuleika,

Peter Carvalho, Deborah Clements, Ben Creagh-Brown

Kettering General Hospital NHS Foundation Trust, Kettering: Philip Watt,

Parizade Raymode

Barts Health NHS Trust, Royal London Hospital, London: Rupert Pearse, Otto Mohr, Ashok Raj, Thais Creary

Newcastle Upon Tyne Hospitals NHS Trust The Freeman Hospital High

Heaton, Newcastle upon Tyne: Ahmed Chishti, Andrea Bell, Charley Higham,

Alistair Cain, Sarah Gibb, Stephen Mowat

Derriford Hospital Plymouth Hospitals NHS Trust, Plymouth: Danielle

Franklin, Claire West, Gary Minto, Nicholas Boyd

Royal Hallamshire Hospital, Sheffield: Gary Mills, Emily Calton, Rachel Walker, Felicity Mackenzie, Branwen Ellison, Helen Roberts

Mid Staffordshire NHS, Stafford: Moses Chikungwa, Clare Jackson

Musgrove Park Hospital, Taunton: Andrew Donovan, Jayne Foot, Elizabeth Homan

South Devon Healthcare NHS Foundation Trust /Torbay Hospital, Torquay,

Torbay: Jane Montgomery, David Portch, Pauline Mercer, Janet Palmer

Royal Cornwall Hospital, Truro: Jonathan Paddle, Anna Fouracres, Amanda

Datson, Alyson Andrew, Leanne Welch

Mid Yorkshire Hospitals NHS Trust; Pinderfields Hospital, Wakefield: Alastair

Rose, Sandeep Varma, Karen Simeson

Sandwell and West Birmingham NHS Trust, West Bromich: Mrutyunjaya

Rambhatla, Jaysimha Susarla, Sudhakar Marri, Krishnan Kodaganallur, Ashok

Das, Shivarajan Algarsamy, Julie Colley

York Teaching Hospitals NHS Foundation Trust, York: Simon Davies,

Margaret Szewczyk, Thomas Smith

United States

University of Colorado School of Medicine/University of Colorado Hospital, Aurora: Ana Fernandez- Bustamante, Elizabeth Luzier, Angela Almagro

Massachusetts General Hospital, Boston: Marcos Vidal Melo, Luiz Fernando, Demet Sulemanji

Mayo Clinic, Rochester: Juraj Sprung, Toby Weingarten, Daryl Kor, Federica Scavonetto, Yeo Tze

\section{Authors' contributions}

CR wrote the first draft of the manuscript, performed the statistical analysis and contributed to conception and design, acquisition of data, or analysis and interpretation of data, to the final drafting the article and revised it critically for important intellectual content; PP wrote the first draft of the manuscript; $\mathrm{DB}$ helped $\mathrm{CR}$ and PP to write the first draft of the manuscript; SNTH, ASN, TB, JC, MH, MHW, GHM, MFVM, CP, SJ, WS, PS, HW, LB, MGA, MJS, $\mathrm{PP}, \mathrm{DB}$ contributed to conception and design, acquisition of data, or analysis and interpretation of data, to the final drafting the article and revised it critically for important intellectual content; all authors have read and approved the submitted manuscript; and agreed that the article is accountable for all aspects of the work thereby ensuring that questions related to the accuracy or integrity of any part of the work are appropriately investigated and resolved.

\section{Funding}

LAS VEGAS was partly sponsored by the European Society of Anaesthesiology and the Amsterdam University Medical Centers, location 'AMC'. It was also funded by a grant from the AAGBI via the NIAA in the UK. MFVM was supported by grant NIH-NHLBI UG3-HL140177. Funders provided support for logistic and study development.

\section{Availability of data and materials}

The dataset used and analysed during the current study are available from the corresponding author on reasonable request.

\section{Ethics approval and consent to participate}

Ethic approval is in accordance with the Declaration of Helsinki and the study was first approved by the ethical committee of the Academic Medical Center, Amsterdam, the Netherlands (W12_190\#12.17.0227). Each participating centre obtained the approval from the local ethical review board, and written informed consent was obtained from patients or next of kin, according to ethical requirements.

\section{Consent for publication}

Not applicable.

\section{Competing interests}

The authors declare that they have no competing interests.

\section{Author details}

'Anaesthesia and Intensive Care, San Martino Policlinico Hospital, IRCCS for Oncology and Neurosciences, Largo Rosanna Benzi 8, 16131 Genoa, Italy. ${ }^{2}$ Department of Intensive Care, Amsterdam University Medical Centers, location 'AMC', Amsterdam, The Netherlands. ${ }^{3}$ Department of Anaesthesiology, Amsterdam University Medical Centers, location 'AMC', Amsterdam, The Netherlands. ${ }^{4}$ Department of Critical Care Medicine, Hospital Israelita Albert Einstein, Sao Paulo, Brazil. ${ }^{5}$ Department of Anaesthesiology and Intensive Care Medicine, Pulmonary engineering group, University Hospital Carl Gustav Carus, Technische Universitat Dresden, Dresden, Germany. ${ }^{6}$ Department of Anaesthesiology and Postoperative Care, Hospital Universitari Germans Trials I Pujol, Barcelona, Spain. ${ }^{7}$ Division Cardiac, Thoracic, Vascular Anesthesia and Intensive Care, Medical University Vienna, Vienna, Austria. ${ }^{8}$ Operating Services, Critical Care and Anaesthesia, Sheffield Teaching Hospitals and University of Sheffield, Sheffield, UK. ${ }^{9}$ Department of Anaesthesia, Critical Care and Pain Medicine, Massachussetts General Hospital, Boston, MA, USA. ${ }^{10}$ Department of Anesthesiology and Intenisve Care Medicine, University Hospital Bonn, Bonn, Germany. ${ }^{11}$ Department of Anaesthesia and Intensive Care, Saint Eloi Montpellier University Hospital, and PhyMedExp, University of Montpellier, Montpellier, France. ${ }^{12}$ Department of Biotechnology and Sciences of Life, ASST-Setteleghi Ospedale di circolo e Fondazione Macchi, University of Insubria, Varese, Italy. ${ }^{13}$ Department of Anesthesiology and Intensive Care Medicine, University of Leipzig, Leipzig, Germany. ${ }^{14}$ Department of Surgical Sciences and Integrated Diagnostics, University of Genoa, Genoa, Italy. ${ }^{15}$ Mahidol-Oxford Tropical Medicine Research Unit (MORU), Mahidol University, Bangkok, Thailand.

Received: 7 February 2020 Accepted: 20 March 2020

Published online: 02 April 2020

\section{References}

1. Del Sorbo L, Goligher EC, McAuley DF, Rubenfeld GD, Brochard L, Gattinoni $L$, et al. Mechanical ventilation in adults with acute respiratory distress syndrome: Summary of the experimental evidence for the clinical practice guideline. Ann Am Thorac Soc. 2017;14(Supplement_4):S261-70.

2. Kienbaum P, Pelosi P, Gama de Abreu M, Meyer-Treschan TA, Serpa Neto A, Schultz MJ, et al. Temporal Changes in Ventilator Settings in Patients With Uninjured Lungs. Anesth Analg. 2018;129:129-40.

3. Serpa Neto A, Hemmes SNT, Barbas CSV, Beiderlinden M, Biehl M, Binnekade $J \mathrm{M}$, et al. Protective versus conventional ventilation for surgery: a systematic review and individual patient data meta-analysis. Anesthesiology. 2015;123: 66-78.

4. Mascia L, Zavala E, Bosma K, Pasero D, Decaroli D, Andrews P, et al. High tidal volume is associated with the development of acute lung injury after severe brain injury: an international observational study. Crit Care Med. 2007;35:1815-20.

5. Pelosi P, Ferguson ND, Frutos-Vivar F, Anzueto A, Putensen C, Raymondos K, et al. Management and outcome of mechanically ventilated neurologic patients. Crit Care Med. 2011;39:1482-92.

6. Borsellino B, Schultz MJ, Gama de Abreu M, Robba C, Bilotta F. Mechanical ventilation in neurocritical care patients: a systematic literature review. Expert Rev Respir Med. 2016;10:1123-32. 
7. Della Torre V, Badenes R, Corradi F, Racca F, Lavinio A, Matta B, et al. Acute respiratory distress syndrome in traumatic brain injury: how do we manage it? J Thorac Dis. 2017:9:5369-81.

8. Rock AK, Opalak CF, Workman KG, Broaddus WC. Safety outcomes following spine and cranial neurosurgery: evidence from the National Surgical Quality Improvement Program. J Neurosurg Anesthesiol. 2018;30:328-36.

9. Soh S, Shim J, Ha Y, Kim YS, Lee H, Kwak YL. Ventilation with high or low tidal volume with PEEP does not influence lung function after spinal surgery in prone position: a randomized controlled trial. J Neurosurg Anesthesiol. 2018:30:237-45.

10. Schultz MJ, Hemmes SNT, Neto AS, Binnekade JM, Canet J, Hedenstierna G, et al. Epidemiology, practice of ventilation and outcome for patients at increased risk of postoperative pulmonary complications: LAS VEGAS - an observational study in 29 countries. Eur J Anaesthesiol. 2017;34:492-507.

11. Paluzie G, Valle J, Castillo J, Ph D, Sabate S, Canet J, et al. Prediction of postoperative pulmonary complications in a population-based surgical cohort. Anesthesiology. 2010;113:1338-50.

12. Gattinoni $L$, Tonetti $T$, Cressoni M, Cadringher $P$, Herrmann $P$, Moerer $O$, et al. Ventilator-related causes of lung injury: the mechanical power. Intensive Care Med. 2016;42:1567-75.

13. Schultz MJ, Haitsma JJ, Slutsky AS, Gajic O. What tidal volumes should be used in patients without acute lung injury? Anesthesiology. 2007;106:122631.

14. Simonis FD, Serpa Neto A, Binnekade JM, Braber A, Bruin KCM, Determann $\mathrm{RM}$, et al. Effect of a low vs intermediate tidal volume strategy on ventilatorfree days in intensive care unit patients without ARDS: a randomized clinical trial. JAMA - J Am Med Assoc. 2018;320:1872-80.

15. Shapiro HM, Marshall LF. Intracranial pressure responses to PEEP in headinjured patients. J Trauma. 1978;18:254-6.

16. Robba C, Bragazzi L, Bertuccio A, Cardim D, Donnelly J, Sekhon M, et al. Effects of prone position and positive end-expiratory pressure on noninvasive estimators of ICP : a pilot study. J Neurosurg aAnesthesiology. 2017;29:243-50.

17. Mascia L, Grasso S, Fiore T, Bruno F, Berardino M, Ducati A. Cerebropulmonary interactions during the application of low levels of positive endexpiratory pressure. Intensive Care Med. 2005;31:373-9.

18. Aldenkortt M, Lysakowski C, Elia N, Tramèr MR. Ventilation strategies in obese patients undergoing surgery: systematic review and meta-analysis. Eur J Anaesthesiol. 2012;109:493-502.

19. Chacko B, Peter JV, Tharyan P, John G, Jeyaseelan L. Pressure-controlled versus volume-controlled ventilation for acute respiratory failure due to acute lung injury (ALI) or acute respiratory distress syndrome (ARDS). Cochrane Database Syst Rev. 2015;1:CD008807.

20. Zhu YQ, Fang F, Ling XM, Huang J, Cang J. Pressure-controlled versus volume-controlled ventilation during one-lung ventilation for video-assisted thoracoscopic lobectomy. J Thorac Dis. 2017;9:1303-9.

21. Kang W-S, Oh C-S, Kwon W-K, Rhee KY, Lee YG, Kim T-H, et al. Effect of mechanical ventilation mode type on intra- and postoperative blood loss in patients undergoing posterior lumbar Interbody fusion surgery. Anesthesiology. 2016;125:115-23.

22. Bagchi A, Rudolph MI, Ng PY, Timm FP, Long DR, Shaefi S, et al. The association of postoperative pulmonary complications in 109,360 patients with pressure-controlled or volume-controlled ventilation. Anaesthesia. 2017;72:1334-43.

23. Cressoni M, Gotti M, Chiurazzi C, Massari D, Algieri I, Amini M, et al. Mechanical power and development of ventilator-induced lung injury. Anesthesiology. 2016;124:1100-8.

24. Güldner A, Kiss T, Serpa Neto A, Hemmes SNT, Canet J, Spieth PM, et al. Intraoperative protective mechanical ventilation for prevention of postoperative pulmonary complications. Anesthesiology. 2015;123:692-713.

25. Fan E, Del Sorbo L, Goligher EC, Hodgson CL, Munshi L, Walkey AJ, et al. An official American Thoracic Society/European society of intensive care medicine/society of critical care medicine clinical practice guideline: mechanical ventilation in adult patients with acute respiratory distress syndrome. Am J Respir Crit Care Med. 2017;195:1253-63.

26. Gajic O, Frutos-Vivar F, Esteban A, Hubmayr RD, Anzueto A. Ventilator settings as a risk factor for acute respiratory distress syndrome in mechanically ventilated patients. Intensive Care Med. 2005;31:922-6.

27. Bluth T, Serpa Neto A, Schultz MJ, Pelosi P, Gama De Abreu M. Effect of Intraoperative High Positive End-Expiratory Pressure (PEEP) with Recruitment Maneuvers vs Low PEEP on Postoperative Pulmonary Complications in
Obese Patients: A Randomized Clinical Trial. JAMA - J Am Med Assoc. 2019; 321:2292-305.

28. Sakr Y, Vincent JL, Reinhart K, Groeneveld J, Michalopoulos A, Sprung CL, et al. High tidal volume and positive fluid balance are associated with worse outcome in acute lung injury. Chest. 2005;128:3098-108.

29. De Jong MA, Ladha KS, Melo MFV, Staehr-Rye AK, Bittner EA, Kurth T, et al. Differential effects of intraoperative positive end-expiratory pressure (PEEP) on respiratory outcome in major abdominal surgery versus craniotomy. Ann Surg. 2016;264:362-9.

30. Pelosi P, Rocco PRM, Gama de Abreu M. Close down the lungs and keep them resting to minimize ventilator-induced lung injury. Crit Care. 2018;22: 72 .

\section{Publisher's Note}

Springer Nature remains neutral with regard to jurisdictional claims in published maps and institutional affiliations.
Ready to submit your research? Choose BMC and benefit from:

- fast, convenient online submission

- thorough peer review by experienced researchers in your field

- rapid publication on acceptance

- support for research data, including large and complex data types

- gold Open Access which fosters wider collaboration and increased citations

- maximum visibility for your research: over $100 \mathrm{M}$ website views per year

At BMC, research is always in progress.

Learn more biomedcentral.com/submissions 